\title{
Antifungal biomaterial for reducing infections caused by Candida albicans in edentulous patients
}

\author{
Laura S. Acosta-Torres, ${ }^{1 *}$ Juan C. Flores-Arriaga, ${ }^{2}$ Paloma N. Serrano-Díaz, ${ }^{1}$ Itzel A. González-García, ${ }^{1}$ \\ Juan C. Viveros-García, ${ }^{3}$ Ma. del Carmen Villanueva-Vilchis, ${ }^{4}$ Francisco G. Villanueva-Sánchez, ${ }^{5}$ \\ René García-Contreras ${ }^{1}$ and Ma. Concepción Arenas-Arrocena ${ }^{1}$ \\ 'Interdisciplinary Research Laboratory, Nanostructures and Biomaterials Area; ${ }^{2}$ Laboratory of Basic Sciences, Faculty of Stomatology, Universidad \\ Autónoma de San Luis Potosí, San Luis Potosí; ${ }^{3}$ Geriatrics Area, Bachelor's Degree in Physiotherapy Program; ${ }^{4}$ Public Oral Health Area, Bachelor's \\ Degree in Dentistry Program; ${ }^{5}$ Interdisciplinary Research Laboratory, Oral and Maxillofacial Pathology Area. $1,3,4,5$ Universidad Nacional Autónoma \\ de México, Escuela Nacional de Estudios Superiores Unidad León, Guanajuato. Mexico
}

\begin{abstract}
Introduction: Polymethylmethacrylate (PMMA) acrylic resins are used to make dentures for edentulous patients. Objective: To find out the prevalence of Candida species in patients with and without removable prostheses from a dental clinic in León, Guanajuato, as well as to assess the antifungal effect and biological behavior of an experimental PMMA with silver nanoparticles for its possible application in prostheses. Method: To identify Candida species, smear samples were obtained from the palatal mucosa of 140 patients aged $\geq 60$ years. The experimental PMMA with silver nnoparticles was placed in Candida albicans cultures, which were stained with the Live/Dead ${ }^{\boxplus}$ kit for analysis under confocal microscopy; subsequently, it was implanted in Wistar rats in order to know its behavior in the surrounding tissues. Results: Candida albicans was the most prevalent species in the evaluated patients, followed by Candida tropicalis and Candida krusei. The acrylic resin with silver nanoparticles significantly decreased the presence of Candida albicans. In the animal model, a discrete and controlled inflammatory reaction was found, which indicated biocompatibility of the acrylic resin that was used. Conclusions: It is possible for the nanostructured material with antifungal effect to be used in order to promote the reduction of oral Candida infections in edentulous patients.
\end{abstract}

KEY WORDS: Silver nanoparticles. Acrylic resin. Antifungal. Biocompatibility in animal model.

\section{Biomaterial antifúngico para reducir las infecciones causadas por Candida albicans en pacientes edéntulos}

\section{Resumen}

Introducción: Las resinas acrílicas de polimetilmetacrilato (PMMA) son utilizadas para elaborar dentaduras para pacientes edéntulos. Objetivo: Conocer la prevalencia de las especies de Candida en pacientes con y sin prótesis removibles de una clínica de odontología en León, Guanajuato; así como valorar el efecto antifúngico y el comportamiento biológico de un PMMA experimental con nanopartículas de plata para su posible aplicación en prótesis. Método: Para identificar las especies de Candida se obtuvieron muestras para frotis de la mucosa palatina de 140 pacientes con edad $\geq 60$ años. El PMMA experimental con nanopartículas de plata fue colocado en cultivos de Candida albicans, los cuales fueron teñidos con el kit Live/ Dead® para su análisis bajo microscopia confocal; posteriormente, se implantó en ratas Wistar para conocer su comportamiento en los tejidos circundantes. Resultados: Candida albicans fue la especie más prevalente en los pacientes valorados, seguida de Candida tropicalis y Candida krusei. La resina acrílica con nanopartículas de plata disminuyó significativamente la

Correspondence:

*Laura S. Acosta-Torres

E-mail: lacosta@enes.unam.mx
Date of reception: 09-12-2020

Date of acceptance: 21-01-2021

DOI: 10.24875/GMM.M21000585
Gac Med Mex. 2021;157:422-427

Contents available at PubMed

www.gacetamedicademexico.com

0016-3813/@ 2021 Academia Nacional de Medicina de México, A.C.. Published by Permanyer. This is an open access article under the CC BY-NC-ND license (http://creativecommons.org/licenses/by-nc-nd/4.0/). 
presencia de Candida albicans. En el modelo animal se encontró reacción inflamatoria discreta y controlada, lo cual indicó la biocompatibilidad de la resina acrílica utilizada. Conclusiones: Es posible utilizar el material nanoestructurado con efecto antifúngico para promover la reducción de infecciones orales por Candida en pacientes edéntulos.

PALABRAS CLAVE: Nanopartículas de plata. Resina acrílica. Antifúngico. Biocompatibilidad en modelo animal.

\section{Introduction}

According to 2012 National Health and Nutrition Survey, in Mexico there are 8874 people aged 60 years or older, which accounts for $9.2 \%$ of estimated population of the country, while by 2050 , it is estimated that older adults will make up nearly $28.0 \%$ of the population. ${ }^{1}$ Regarding patient oral health, edentulism is complete loss of all natural teeth, which causes chewing difficulties and leads to nutritional deficiencies, social isolation and depression. ${ }^{2}$ Edentulism causes for patients to require the use of dental prostheses, which predisposes them to infections such as sub-prosthetic stomatitis due to colonization by Candida albicans, which in Mexico has a prevalence of $65 \%{ }^{3}$ Microorganisms of the Candida genus are a group of yeasts with opportunistic behavior that is part of oral mucosa ecosystem; ${ }^{4}$. albicans is the most common species.

On the other hand, the material total prostheses or dentures are made of is polymethyl methacrylate (PMMA) acrylic resin, given that it has desirable physicochemical properties, but it requires constant hygiene in order to avoid microorganism accumulation. ${ }^{5}$ In addition, there are multiple predisposing factors for candidiasis such as reduced salivary flow, use of corticosteroids, unadjusted dental prostheses, malnutrition, endocrine, and immune disorders, among others. $^{6}$

Currently, there is no commercial biomaterial for dentures with antimicrobial effect; however, in dentistry, the use of nanoparticles is a cutting-edge technology that can substantially modify the physical, chemical, and biological properties of materials; therefore, the purpose of this research was to find out the most prevalent Candida species in Mexican patients who use dental prostheses, as well as to evaluate the antifungal effect against $C$. albicans of an experimental acrylic resin with silver nanoparticles for application in dentures and biocompatibility in an animal model.

\section{Method}

A cross-sectional study was carried out, with a first phase to determine patient sociodemographic characteristics and Candida species prevalence. One hundred and forty patients aged 60 years and older who attended the Dentistry Clinic at the National School of Higher Education, León Unit, National Autonomous University of Mexico, were chosen by convenience during 2019. In all of them, medical history was obtained and sociodemographic information on variables was collected, including age, gender, marital status and place of origin. Whether the patients were users of dental prostheses or not was also recorded.

\section{Sample taking for Candida identification}

All patients signed the informed consent document before mucosal swab sample collection. Palatal mucosa swab samples were obtained under aseptic conditions with Stuart ${ }^{\circledR}$ kit (Thermo Fisher Scientific, Spain) for biological samples collection and transport. Each tube was labeled and sealed for transportation to the laboratory. The samples were seeded in Petri dishes with CHROMagar Candida, for which the streaking method was used; subsequently, the samples were incubated at $35 \pm 2 \stackrel{\circ}{\circ}$ for 48 hours. The results were recorded according to the coloration of each sample, based on the contrast medium specifications: green-colored colonies, C. albicans; colonies in pink, Candida krusei; colonies in blue, Candida tropicalis. The results of patients with and without dental prostheses who had or had not Candida different species growth are reported, according to $\chi^{2}$ statistical analysis.

\section{Experimental acrylic resin and silver nanoparticles}

A PMMA acrylic resin, synthesized at the Interdisciplinary Research Laboratory where the study was carried out, was used. PMMA is a pink-colored acrylic resin formed of 10-30 $\mu \mathrm{m}$ spherical particles developed by Acosta Torres et al., the synthesis and characterization of which was published in 2014. ${ }^{7}$ The silver nanoparticles (AgNP) were synthesized at the same laboratory and by the same research group, and their formulation was published in 2011. ${ }^{8}$ These nanoparticles have a 
20-50-nm semispherical morphology. PMMA with or without AgNPs has been previously evaluated in cultures with human gingival fibroblasts at 24 and 48 hours, with no reported cytotoxic effects or significant differences with the control group. ${ }^{?}$

\section{PMMA and PMMA-AgNP samples preparation}

PMMA and PMMA-AgNP $(0.2 \mu \mathrm{g} / \mathrm{mL}$ AgNP) acrylic resin discs of $10 \mathrm{~mm}$ in diameter $\times 2 \mathrm{~mm}$ thickness ${ }^{7}$ were manufactured for antifungal effect and biocompatibility tests to be performed in an animal model $(n=10)$. The samples were washed and sterilized with ultraviolet light for 10 minutes.

\section{Antifungal effect evaluation}

C. albicans biofilms (ATCC 90026) were deposited on PMMA and PMMA-AgNP discs and observed by confocal laser scanning microscopy (Leica SP5 ${ }^{\circledR}$ ). The acrylic samples were stained for 15 minutes prior to obtaining images with Live/dead BacLight ${ }^{\mathrm{TM}}$ colorant prepared with $1 \mathrm{~mL}$ sterile distilled water, $1 \mathrm{~mL}$ SYTO'M 9 fluorescent nucleic acid green colorant, $1 \mathrm{~mL}$ fluorescent red stain with nucleic acid and propidium iodide.

\section{Biocompatibility in an animal model}

PMMA and PMMA-AgNP discs were surgically implanted in the back of 30 Wistar rats, to assess their effect at 15 and 45 days $(n=15)$. As control group, 15 Wistar rats that had no disc implanted were used. After each time period was elapsed, the animals were sacrificed and samples were obtained for biopsy of acrylic discs implant area surrounding tissues, in accordance with ISO 10993-6. ${ }^{9}$ The samples were prepared for histological processing, embedded in paraffin blocks, and microtome sections and hematoxylin-eosin staining were carried out for observation with an optical microscope. ${ }^{10}$

\section{Ethical considerations}

The protocol for patient palate swab sample-taking was approved by the Research Ethics Commission of the National School of Higher Education, León Unit (CE_17/009); patient voluntary participation was obtained. The protocol for the animal model assay was approved by the Ethics Commission of the same school (CEl.19_033_S8E).

\section{Results}

Of the 140 assessed patients, $63.6 \%$ corresponded to the female gender. Mean age was 69 years (60 to 92 years). Distribution by marital status showed that $66.4 \%$ were married and $33.6 \%$ were single. By state of origin, $66.4 \%$ of the patients were born in Guanajuato and $33.63 \%$ in another state of the Republic.

Forty-eight patients with prostheses were found, 21 with partial prosthesis and 27 with total prosthesis (denture). C. albicans was found in $65.1 \%$ of the patients and thus it constituted the most prevalent species. According to the data shown in table 1, it can be inferred that there were no statistically significant differences between the patients who tested positive for C. albicans whether they used a dental prosthesis or not. The same behavior was observed in patients with and without prostheses who tested positive for $C$. tropicalis. However, a significant difference was found in C. krusei-positive patients when they used a dental prosthesis or not, which showed that the use of prostheses favors proliferation of this microorganism.

\section{Antifungal effect evaluation}

Confocal microscopy images show the PMMA and PMMA-AgNP discs surfaces at $2.5 \mathrm{D}$. In the PMMA group, C. albicans cells were observed in green, which indicates their viability (Fig. $1 A$ and $B$ ). The group with PMMA-AgNP shows green and red fluorochromes; the red color is indicative of $C$. albicans dead cells (Fig. 1C and D).

\section{PMMA and PMMA-AgNP histological evaluation in an animal model}

The evaluated histological sections show the presence of a pseudocapsule associated with the niche of the implanted material; a discrete and controlled predominantly lymphoplasmacytic inflammatory reaction limited to the capsule was observed, as well as isolated multinucleated giant cells, which denotes the biocompatibility of the used material.

Figure 2 shows microscopic images of chronic inflammatory infiltrate cells and giant cells as evidence of foreign body reaction. After analyzing animal samples cellular behavior (Table 2), it is possible to say 
Table 1. Total number of patients who were carriers and not of dental prostheses who showed Candida albicans, tropicalis or krusei

\begin{tabular}{l|c|c|c|c|}
\hline & \multicolumn{4}{|c|}{ Patients with Candida $(\%)$} \\
\cline { 2 - 5 } Carriers or not of prosthesis & Total $(\mathrm{n})$ & albicans & tropicalis & krusei \\
\hline Patients carrying partial or total prostheses & 48 & 35.4 & 16.7 & 31.3 \\
\hline Patients not carrying prosthesis & 92 & 29.7 & 16.7 & 12.2 \\
& & $\chi^{2}=0.480, p=0.489$ & $\chi^{2}=0.018, p=0.892$ & $\chi^{2}=7.412, p=0.006$
\end{tabular}

C. albicans: Candida albicans; C. tropicalis: Candida tropicalis; C. krusei: Candida krusei

Table 2. Description of the histopathological analysis of the samples obtained from the animals at 15 and 45 days of exposure to PMMA and PMMA-AgNP

\begin{tabular}{|c|c|c|c|c|c|c|}
\hline \multirow[t]{2}{*}{ Characteristic } & \multicolumn{3}{|c|}{15 days } & \multicolumn{3}{|c|}{45 days } \\
\hline & Control & PMMA & PMMA-AgNP & Control & PMMA & PMMA-AgNP \\
\hline $\begin{array}{l}\text { Type of } \\
\text { inflammation }\end{array}$ & Absent & $80 \%$ chronic & $60 \%$ mixed & Absent & $100 \%$ mixed & $90 \%$ mixed \\
\hline Severity & $\begin{array}{l}\text { No inflammatory } \\
\text { cells detected }\end{array}$ & $\begin{array}{l}40 \% \text { moderate, } \\
40 \% \text { mild }\end{array}$ & $\begin{array}{l}60 \% \text { moderate, } \\
20 \% \text { severe }\end{array}$ & $\begin{array}{l}\text { No inflammatory } \\
\text { cells detected }\end{array}$ & $60 \%$ mild & $50 \%$ mild \\
\hline Extension & $\begin{array}{l}\text { No inflammatory } \\
\text { cells detected }\end{array}$ & $\begin{array}{l}90 \% \text { limited to the } \\
\text { capsule }\end{array}$ & $\begin{array}{l}90 \% \text { limited to } \\
\text { the capsule }\end{array}$ & $\begin{array}{l}\text { No inflammatory } \\
\text { cells detected }\end{array}$ & $\begin{array}{l}100 \% \text { limited to } \\
\text { the capsule }\end{array}$ & $\begin{array}{l}100 \% \text { limited to } \\
\text { the capsule }\end{array}$ \\
\hline $\begin{array}{l}\text { Foreign body } \\
\text { reaction }\end{array}$ & Absent & $70 \%$ present & $80 \%$ present & Absent & $100 \%$ absent & $90 \%$ absent \\
\hline
\end{tabular}

A
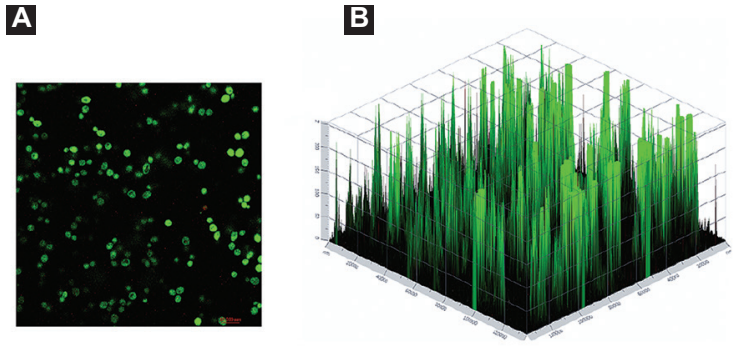

C
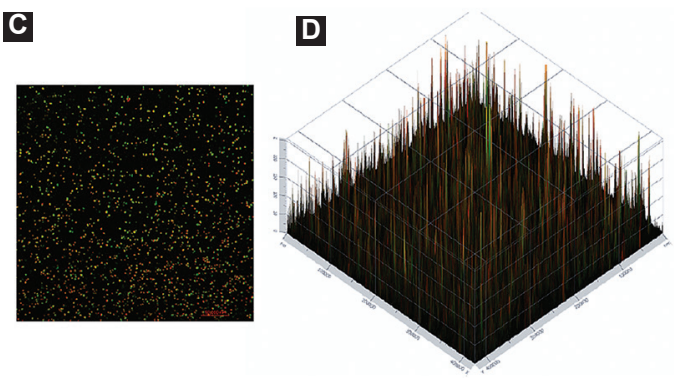

Figure 1. Confocal microscopy. (A and B) Candida albicans live cells (green) on a PMMA substrate. (C and D) C. albicans dead cells (red) on a PMMA-AgNP substrate, indicating damage by the effect of silver nanoparticles.

that, after 45 days, there was $100 \%$ mixed inflammation of mild severity, and that foreign body reactions were absent in $90 \%$. Therefore, the developed material is considered biocompatible when evaluated in an animal model and viable for application in the next stage of clinical evaluation.

\section{Discussion}

The Mexican population that attends university clinics has a high prevalence $(65.1 \%)$ of $C$. albicans. Regarding the use of prostheses, De Calvalho-Bianchi et al., in 2016, carried out a study where they isolated different Candida species; they found that advanced age people with removable prostheses were 4.4 times more likely to have Candida isolated than people who did not use them $(95 \% \mathrm{Cl}=1.65-11.4){ }^{11}$ In contrast, in the present study, we only verified an association with the use of prostheses with $C$. krusei, probably due to the fact that only 48 subjects in the entire sample referred using prostheses.

The acrylic resin developed with silver nanoparticles has an antifungal effect that inhibits Candida, which will contribute to treatment in patients with sub-prosthetic stomatitis, and probably they will not require additional pharmacological treatment. In other studies, silver nanoparticles have also shown an antimicrobial effect, without being toxic when they 


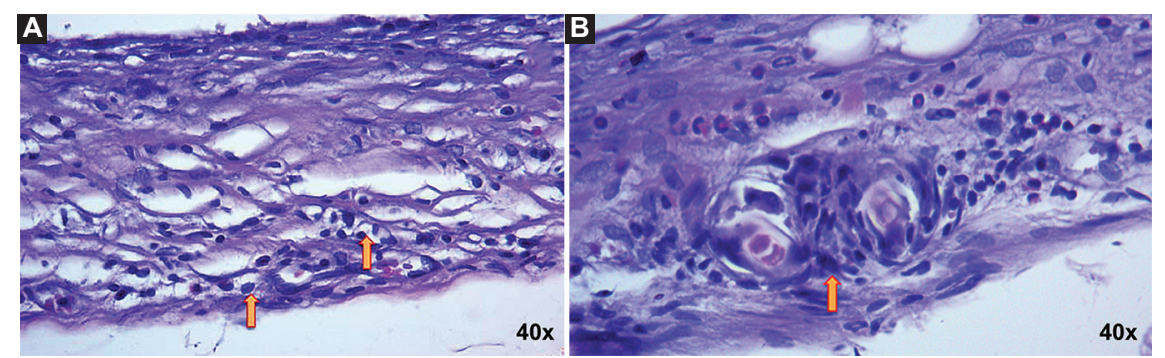

Figure 2. Microscopic analysis of histological samples taken from Wistar rats after being exposed to the experimental acrylic resin. A) Tissue in contact with PMMA shows predominantly lymphoplasmacytic chronic inflammatory infiltrate (arrows). B) Tissue in contact with PMMA-AgNP shows foreign body reaction, isolated giant cells (arrows). $P M M A=$ polymethyl methacrylate, $P M M A-A g N P=$ polymethyl methacrylate with silver nanoparticles.

have a size of 20 to $50 \mathrm{~nm}$, and constitute a possible alternative to the use of antibiotics without causing microbial resistance. ${ }^{12}$ The reagents used to synthesize the silver nanoparticles are of low cost and, therefore, this option could be affordable for all patients. The proposed acrylic resin is easy to manipulate and available to dentists and dental technicians who manufacture dentures, since the material can directly reduce microbial colonization and serve as an agent for preventing oral infections in older adults.

\section{Conclusions}

An acrylic resin for dentures was developed, based on PMMA microparticles with silver nanoparticles added, as a proposal for edentulous patients with Candida infections. PMMA with silver nanoparticles has an antifungal effect that causes $C$. albicans inhibition. Previous PMMA and PMMA-AgNP in vitro tests indicate that the material is not cytotoxic and, thus, performing a non-invasive in vivo study was considered by placing the experimental acrylic resin in an animal model, which turned out to be biocompatible when the effect on living tissues was evaluated, which is why proposing the product for clinical evaluation in patients will be considered.

\section{Acknowledgments}

The authors thank the National Autonomous University of Mexico Academic Personnel Affairs General Directorate for the postdoctoral scholarship granted to Dr. Juan Carlos Flores Arriaga. The authors also thank professor Lourdes Palma Tirado for transmission electron microscopy analysis; to Dr. Genoveva Hernández Padrón, for Fourier-transform infrared spectroscopy analysis; and to Dr. Marina Vega González, for scanning electron microscopy analysis.

\section{Conflict of interests}

The authors declare that they have no conflicts of interest.

\section{Funding}

The resources for this research were partially obtained from the PAPIIT-IN225516 and PAPIIT-IN115018 projects.

\section{Ethical disclosures}

Protection of human and animal subjects. The authors declare that the procedures that were followed adhered to the ethical standards of the responsible committee for experimentation on human beings and were in agreement with the World Medical Association and the Declaration of Helsinki.

Confidentiality of data. The authors declare that they followed the protocols of their work center on the publication of patient data.

Right to privacy and informed consent. The authors obtained informed consent from the patients or subjects referred to in the article. This document is in the possession of the corresponding author.

\section{References}

1. Encuesta Nacional de Salud y Nutrición. Resultados Nacionales. Mexico: Instituto Nacional de Salud Pública; 2012.

2. Gil-Montoya JA, Ferreira-de Mello AL, Barrios R, González-Moles MA, Bravo M. Oral health in the elderly patient and its impact on general well-being: a nonsystematic review. Clin Interv Aging. 2015;10:461-7.

3. Patil S, Rao RS, Majumdar B, Anil S. Clinical appearance of oral candida infection and therapeutic strategies. Front Microbiol. 2015; 17:1391.

4. De la Rosa-García E, Miramontes-Zapata M, Sánchez-Vargas LO, Mondragón-Padilla A. Colonización e infección bucal por Candida sp. en pacientes diabéticos y no diabéticos con enfermedad renal crónica en diálisis. Nefrologia (Madr). 2013;33:764-70.

5. Pattanaik S, Bvj V, Pattanaik B, Sahu S, Lodam S. Denture stomatitis: a literature review. J Indian Acad Oral Med Radiol. 2010;22:136-40. 
6. Darwazeh, AMG, Darwazeh TA. What makes. Oral candidiasis recurrent infection? A clinical view. J Mycol. 2014;4:758394

7. Acosta-Torres LS, Arenas-Arrocena MC, Núñez-Anita RE, Barceló-Santana FH, Álvarez-Gayosso C, Palacios-Alquisira J, et al. Nanopigmented acrylic resin cured indistinctively by water bath or microwave energy for dentures. J Nanomat. 2014;2014:3-10.

8. Acosta-Torres LS, Mendieta I, Núñez-Anita RE, Cajero-Juárez M, Castaño VM. Cytocompatible antifungal acrylic resin containing silver nanoparticles for dentures. Int J Nanomedicine. 2012;7:4777-86.

9. Biological Evaluation of Medical Devices Part 6: tests for Local Effects after Implantation. Switzerland: International Organization for Standardization; 2016.
10. Taha NA, Safadi RA, Alwedaie MS. Biocompatibility evaluation of endosequence root repair paste in the connective tissue of rats. J Endod. 2016;42:1523-8

11. De Calvalho-Bianchi CM, Aparecido-Bianchi H, Tadano T, Rodrigues-de Paula C, Hoffmann-Santos HD, Pereira-Leite D, Hahn RC. Factors related to oral candidiasis in elderly users and non-users of removable dental prostheses. Rev Inst Med Trop Sao Paulo. 2106; 58:17.

12. Marambio-Jones C, Hoek EM. A review of the antibacterial effects of silver nanomaterials and potential implications for human health and the environment. J Nanopart Res. 2010;12:1531-51. 